\title{
微 流速計の利用とその解釈
}

\author{
羽田 \\ 忍* \\ The Application of Microflowmeter to Engineering Geology \\ Shinobu HADA
}

\begin{abstract}
Measurement of the vertical water velocities flowing through a bore-hole when the water is pumped out or injected will indicate the position of inlets or outlets in the hole.

Lowered into a bore-hole or into a suitable piezometric installation, Microflowmeter makes it possible to measure natural rates of flow and rates following pumping in and pumping out of water, and hence to deduce the petmeability of the strata which the bore-hole crosses.

The instrument we have used consists of a propellor and a photo cell detection system, and is particularly suitable for bore-hole measurements.

Some examples of the test show that the measurement of the vertical water velocities flowing through a bore-hole is useful not only to determine the permeability of strata, but also to estimate the behavior of ground water through the basement rock of dames and around tunnels.
\end{abstract}

\section{1. まえがき}

ボーリング孔内や井戸水の流動状況を測定し，地下水 や地質構造の手掛りとする試みは，かなり古くからおこ 交わていたらしい。1961年の第 5 回国際土質基礎 工学会議 (パリー会議) に扔いて, H. Camfort そ G. Mazier が，井戸の地下水垂直流速の測定について述べ ている。最近では, 孔内水の流動度測定検査方法と称す る特許 (特公昭 45-25029) もあり, この方法では, 図-1 にしめしたような円板を孔内に降下して，円板にかかる 孔内水の上昇流下降流の圧力によって，八カリの示毛 さの変化（図-2）を読みとり流動状況を推定しょうとす るものである。

これから述べる方法は, 微流速計（フランス国, Socosor 社製）を用い，ボーリング孔内に打ける地下水 （孔内水）の流動を測定するもので，いくつかの測定例 と, 測定によって解明された地質状況に関する見解も述 べる。

我国に打ける土木地質領域では, 孔内微流速計の適用 例に乏しいのが実情であり，本論文が，多少なりとも参 考になれば幸いである。また，今後の微流速計利用につ

* 株式会社 応用地質調查事務所
いて，御批判と御教示觉とくに打願いする次第である。 本論に抢ける現場計測・実験には，株式会社応用地質。 調查事務所の技術者多数の協力があった。ここに明記し て感謝の意を表する次第である。

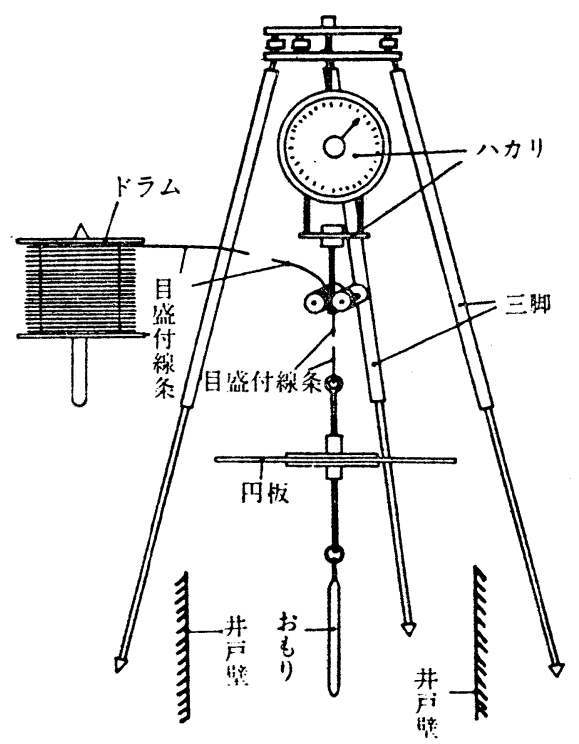

図-1 孔水内流動測定器 


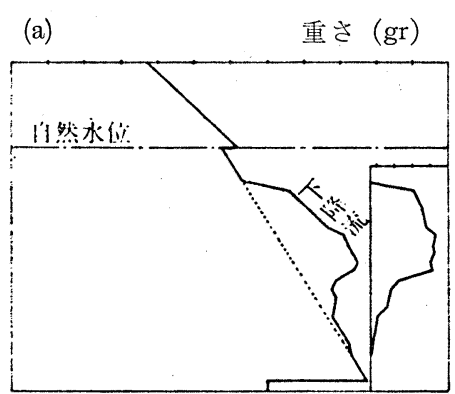

(b)

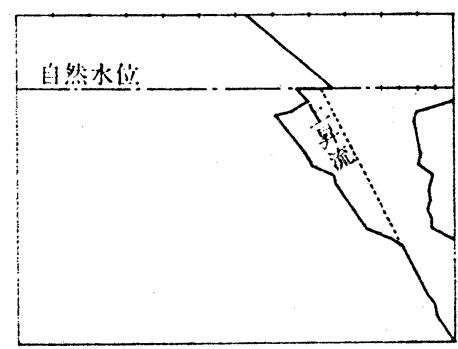

図-2 流動測定器測定例
る流速計と同様の装置である。しかし，ボーリング孔内 のような場所で使用するため，次のような点がとくに考 慮されて作られている。

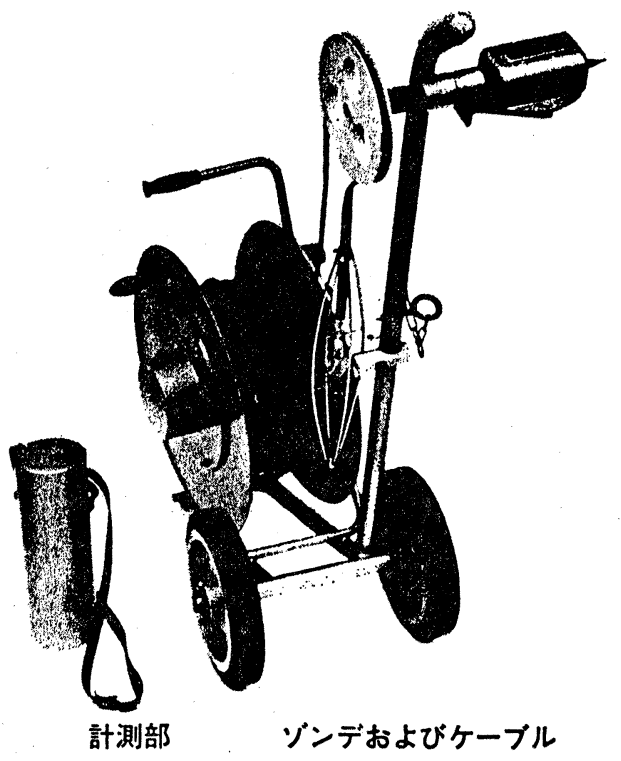

図-3 微流測計

（1）特 徵

微流速計は, 原理的には, 河川の流量測定に用いられ

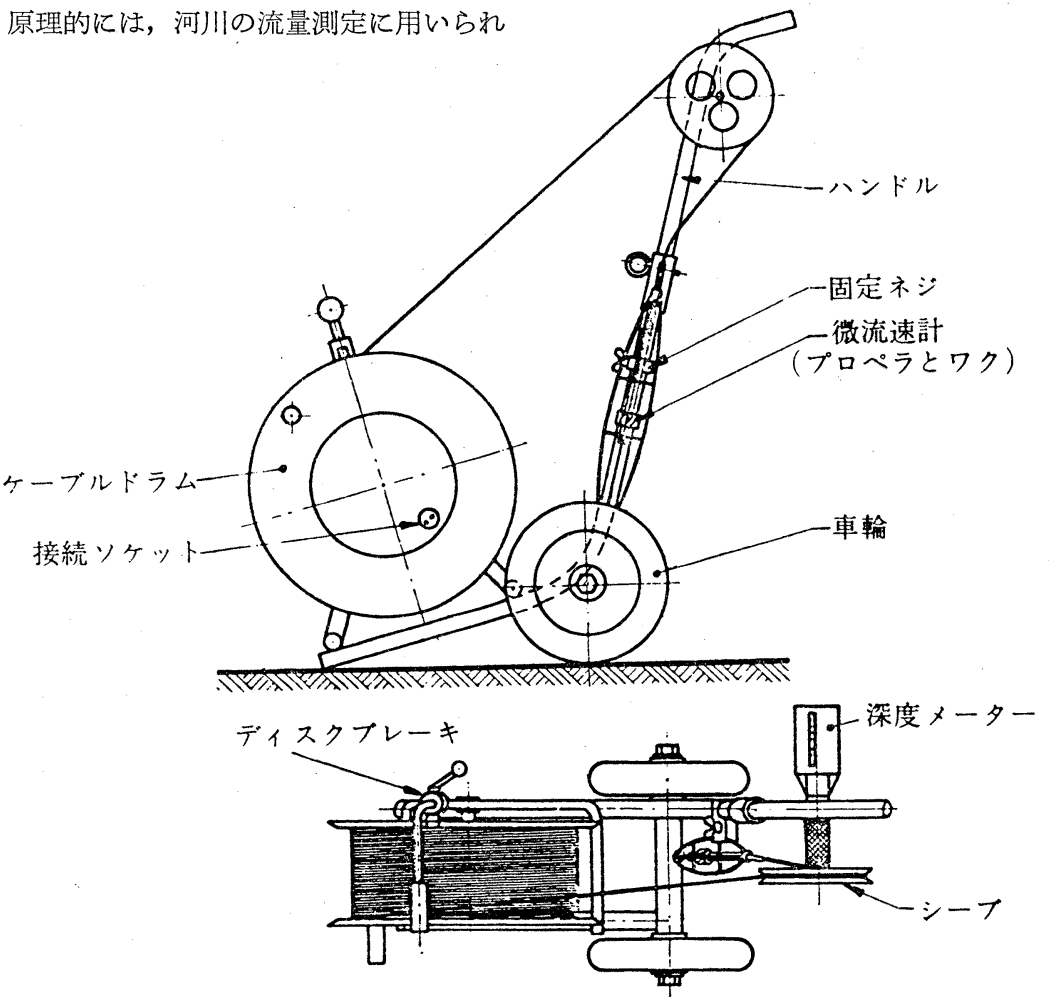

図-4 微流速計の概要図 (MICROMOULINET) 
i）低流速の測定ができるとと。

ii）測定による抵抗によって，水の流秃に影響学与え ないとと。

このために，流速計のプロペラの比重を，測定する流 体（水）と近べること，プロペラの回転数の検出のた め，磁石（力）や抵抗体を用いるシステムによらず，光 電素子学使用する検出法が採用されている。磁石や抵抗 を用いる検出方法は，羽根の回転に多少なりともトルク をあたえるからである。

(2) 構 成(図-3, 図-4)

微流速計は, 地表に置かれる測定計器部と孔内に降下
するゾンデ部およびケーブルとからなる。

i) 地表測定計器部

プロペラの回転数を表示する計測器本体，ケーブルを 収納するドラム，ケーブルのくり出し長さ定測る円板シ ーブと $1 \mathrm{~cm}$ 迄読み取り可能の深度計および車輪付架台 とからなっている。

ii） ゾンデ部

電球と光電素子からなる回転数検出部，光線遮断・開 放のシャッターを軸に備えたプラスチックプロペラ，お よびフレームからなっている。プロペラは，4枚羽根 (低流速用) と 6 枚羽根（高流速用）とが準備されて

表-1 孔内微流速計による試験結果記録

\begin{tabular}{|c|c|c|c|c|c|c|c|c|c|c|c|}
\hline \multicolumn{2}{|c|}{ 調查名 } & \multicolumn{5}{|c|}{ 下金田ダ公地真解析業洜 } & \multicolumn{5}{|c|}{ 調查年月日；昭和5/年8月3日 } \\
\hline \multicolumn{2}{|c|}{ 調查地 } & \multicolumn{5}{|c|}{ 広島是庄裳市水越斩大田 } & \multicolumn{5}{|c|}{ 地盤標高；182.74 m } \\
\hline 地， & 点 ; & No. 30 & & & & & \multicolumn{5}{|c|}{ 地下水位；G．ＯＯm } \\
\hline \multicolumn{2}{|c|}{ 檪根a毫别； } & \multicolumn{2}{|l|}{ 6放羽根 } & \multicolumn{3}{|c|}{ 作賞時闻；12.00 15.00 } & \multicolumn{5}{|c|}{ 測定者；莱昌，久次米，潒原 } \\
\hline $\begin{array}{l}\text { 深度 } \\
(m)\end{array}$ & $\begin{array}{l}\text { 時间 } \\
(\sec )\end{array}$ & \begin{tabular}{|c|}
$27 y_{1}-0$ \\
回転 \\
$(\pi)$ \\
\end{tabular} & $\begin{array}{l}\text { 水流 } \\
\text { 才。 } \\
(t .-) \\
(t .)\end{array}$ & $\begin{array}{l}\text { 每秒当 } 409 \\
\text { 回鞋数 } \\
(n / \mathrm{sec})\end{array}$ & $\begin{array}{l}\text { 孔流速 } \\
\left(v^{\mathrm{cm} / \mathrm{sec}}\right)\end{array}$ & $\begin{array}{l}\text { 深度 } \\
(m)\end{array}$ & $\begin{array}{l}\text { 時间 } \\
(\sec )\end{array}$ & $\begin{array}{c}2 y_{2}-9 \\
\text { 回転数 } \\
(n)\end{array}$ & $\begin{array}{l}\text { 水流 } \\
\text { 方向 } \\
(t,-)\end{array}$ & 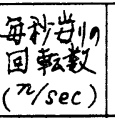 & $\begin{array}{l}\text { 孔内流速 } \\
\left(v^{\mathrm{c} m} / \mathrm{sec}\right)\end{array}$ \\
\hline 1 & 20 & 70 & + & 3.55 & 64.21 & 241 & 10 & 63 & + & 6.3 & $1 / 3.03$ \\
\hline $2 !$ & 20 & 68 & + & 3.4 & 61.55 & $26 !$ & 10 & 68 & + & 6.8 & 121,90 \\
\hline $3:$ & 20 & 71 & + & $3.5-5$ & 64.21 & $27 !$ & 10 & 68 & + & 6.8 & 121.90 \\
\hline 41 & 20 & 74 & + & 3.7 & 65.88 & 281 & 10 & 67 & + & 6.7 & 120.13 \\
\hline F: & 20 & $\geqslant$ & + & 3.55 & 64.21 & 301 & 10 & 69 & + & 6.9 & 123.68 \\
\hline $8:$ & 20 & 71 & + & 3.55 & 641.21 & $32 !$ & 10 & 68 & \pm & 6.8 & 121.90 \\
\hline $9 i$ & 20 & 20 & + & 3.5 & 63.33 & $33 !$ & 10 & 64 & \pm & 6.4 & 114.80 \\
\hline 2:50 & 20 & 70 & + & 3.5 & 63.33 & $34^{\prime}$ & 10 & 68 & + & 6.8 & 121.90 \\
\hline $10 i$ & 20 & 76 & + & 3.8 & 68.65 & 351 & 10 & 67 & + & 6.7 & 120.13 \\
\hline $10: 025$ & 20 & 86 & + & 4.3 & 77.53 & $36 !$ & 10 & 67 & + & 6.7 & 120.13 \\
\hline 10,050 & 2.0 & 91 & + & 4.5 & 81.08 & $32 i$ & 10 & 65 & + & 6.5 & $1 / 6.58$ \\
\hline $10: 075$ & 20 & 100 & + & 5.0 & 89.95 & 381 & 10 & 66 & + & 6.6 & 118.35 \\
\hline $10: 10$ & 20 & 110 & + & 5.0 & 89.95 & 3815 & 10 & 60 & + & 6.0 & 107.70 \\
\hline $10: 20$ & 20 & 117 & + & 5.85 & 105,04 & $39^{\prime}$ & 10 & 61 & + & 6.1 & 109.48 \\
\hline $10 ! 50$ & 20 & 120 & + & 6.0 & 107.70 & $4 a$ & 10 & 64 & \pm & 6.4 & 114.80 \\
\hline $11^{i}$ & 20 & 120 & + & 6.0 & 107.70 & $40: 5$ & 10 & 58 & + & 5.8 & 104.15 \\
\hline $12 i$ & 10 & 64 & + & 6.4 & 114.80 & $4 I_{1}^{\prime}$ & 10 & 58 & \pm & 5.8 & 104.15 \\
\hline 141 & 10 & 61 & + & 6.1 & 109.48 & $42 !$ & 10 & 58 & + & 5.8 & 104.15 \\
\hline $16 i$ & 10 & 63 & + & 6.3 & 113.03 & 44 & 10 & 56 & \pm & 5.6 & 100.60 \\
\hline $18:$ & 10 & 61 & + & 6.1 & 109.48 & $4 b_{1}^{\prime}$ & 10 & 57 & + & 5.7 & 102.38 \\
\hline 20 & 10 & 61 & + & 6.1 & 109.48 & 47 & 10 & 56 & + & 5.6 & 100.60 \\
\hline $22:$ & 10 & 63 & + & 6.3 & 113.03 & : & & & & & \\
\hline & & & & & & & & & & & \\
\hline 速度滥 & $\varphi=7$ & (孔彺8 & $0-40$ & $\begin{array}{r}4 \text { 玟 } \\
V \\
\end{array}$ & $\begin{array}{l}=7.65 \times \bar{n}+0.5 \\
\text {. }\end{array}$ & & 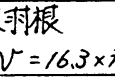 & & $\begin{array}{r}\text { 透水保 } \\
\quad k\end{array}$ & 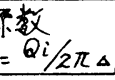 & $p \ln \frac{R}{r}$ \\
\hline 速度;㾞 & 本 $\phi=42$ & $27 / x($ 马经 & $52 \sim 6$ & 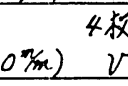 & 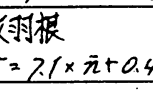 & 6 权 & $\begin{array}{l}\text { 对根 } \\
V=17.75\end{array}$ & $\bar{n}+1.2$ & & & \\
\hline
\end{tabular}


り,またフレームは, 外径 $42 \mathrm{~m} / \mathrm{m}$ のものと外径 70 $\mathrm{m} / \mathrm{m}$ のものとがあり，ボーリング孔径の大小によって 取りかえるようになっている。

\section{(3) 特 性}

i) 適用温度範囲 $\quad 0^{\circ} \mathrm{C} \sim 45^{\circ} \mathrm{C}$

ii) 内部電源 9 volts (単 1 乾電池 $\times 6$ 工)

iii) 外部電源 12 volts

iv）測定持続時間 内部電源 $($ 単 1 乾電池 $\times 6)$ に より, 毎分 400 回転の場合, $20^{\circ} \mathrm{C}$ 条件下で約 20 時間

v）流速測定範囲 $2 \sim 200 \mathrm{~cm} / \mathrm{s}$

vi）標準ケーブル長 $100 \mathrm{~m}$ 最大ケーブル長 $400 \mathrm{~m}$

\section{3. 微流速計による測定}

微流速計を使用するボーリング孔は，孔内を入念に洗 浄し，孔壁崩壞の恐れがないか，事前に充分に検討して おく。このために，微流速計のゾンデ部（フレーム）に 似たダミ一を作成して打き，孔底迄一旦降下して，孔壁 状況崩壞の有無它確認しておくのがよい。

\section{（1）測定作業}

ゾンデをボーリング孔内に降下する。その際，プロペ ラ位置を基準点（通常ケーシング頭：ボーリング深度基 準点）に一致させ，深度計目盛りを０亿合わせて和く。

通常は，孔底迄ゾンデを降下し，流速を測定しながら ゾンデを引揚げる。測定結果は, 表-1のようにデーター シートに記入する。測定間隔は，一般に $0.5 \mathrm{~m}$ 和き位で あるが，流速変化の急変する個所では， $0.1 \mathrm{~m}$ おきに， あるいは変化のない区間では, $1.0 \mathrm{~m} \sim 2.0 \mathrm{~m}$ 間隔に適宜 に実施してもよい。

孔内水の垂直流速が上昇か下降かの判定は，ケーブル を上下に移動させた時，カウントの変化を見れば比較的 容易に扔こなえる。すなわち，ケーブルを上向きに引き
あげた時，カウント数が減少するならば水流は上向き （十）で，逆に増加するならば，水流は下向き（一)であ る。

測定結果は，ボーリング柱状図に併記してしめす。羽 根の回転数から流速に換算するのは，実験によって求め た換算式によるが，との微流速計の場合，打括む牧次式 を用いている。

i）フレーム径 $42 \mathrm{~m} / \mathrm{m}$ ：孔径 $66 \mathrm{~m} / \mathrm{m}$ の場合 4 枚羽根使用： 流速 $v \mathrm{~cm}=7.1 \times n / \mathrm{sec}+0.4$ 6 枚羽根使用： 流速 $v \mathrm{~cm}=17.75 \times n / \mathrm{sec}+0.4$

ii）フレーム径 $70 \mathrm{~m} / \mathrm{m}$ ： 孔径 $86 \mathrm{~m} / \mathrm{m}$ の場合 4 枚羽根使用： 流速 $v \mathrm{~cm}=7.65 \times n / \mathrm{sec}+0.3$ 6 枚羽根使用： 流速 $v \mathrm{~cm}=16.3 \times n / \mathrm{sec}+1.3$

換算式中の $n$ は, 羽根の回転数である。測定に際して $n$ は 10 回以上になるまで測定する必要がある。したが って，流速が遅い場合には，60 sec 以上の時間定かけて 回転数を計ることになる。

\section{(2) 測定結果の解釈}

ボーリング孔内に括ける垂直方向の自然流速の測定の みでは有効な結果は得られない。すなわち，自然状態の 測定では，流速增加部分と減少部分の一組ないし数組の 組合せが示されるのみで，帯水層から溥水しているか， 逆に逃水しているかの情報が得られるにすぎない。

ボーリング孔内の自然水位を揚水し(あるいは注水し) 変化させて流速測定を扢こない，自然状態の水位におけ る流速測定結果と比較して，はじめて有効な解釈が可能 となる。

微流速計による孔内流速の測定結果を模式図として 図-5 にしめす。図-5 の左側の曲線は自然水位に打忊る 測定結果で，孔内水流が下向きであることをしめしてい る。右側の曲線は, 孔内水它汲久出して, 水位が低下し ている時の測定結果で，水流の向きは上向きである。測 定された曲線に対する解釈は次のようになる。

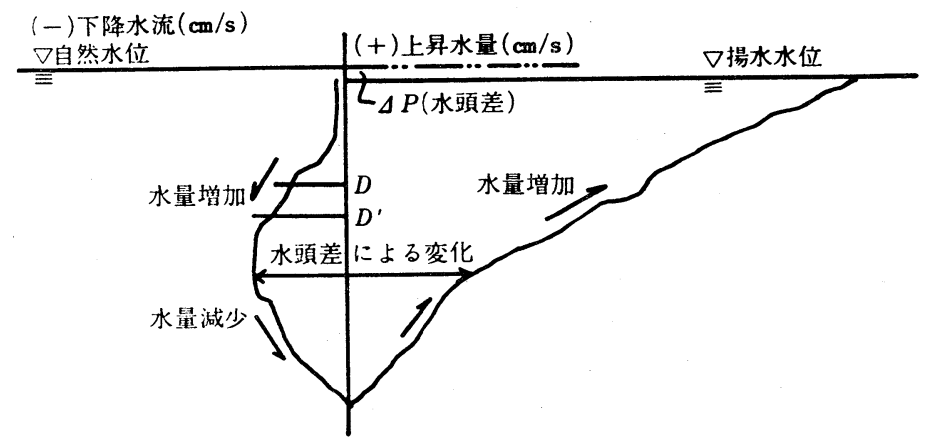

図-5 微流速計による孔内流速測定 
i）上昇している水の速度がしだいに早くなるのは， 孔壁からボーリング孔内に湧水していることを意味す る。つまり, 孔の断面積 $(s) \times$ 流速 $(v)$ 流量 $(Q)$ であ り，ボーリング孔径が同一であれば流速変化は流量变化 となるからである。

ii）下降している水の速度がしだいに早くなるのも， i）と同じ理由から湧水があることになる。

iii）上昇あるいは下降している孔内水の流速がその方 向で次第に減少する場合は，その区間に沶いて，孔壁か ら逃水していることを意味している。

iv）図-5 の自然水位に扔ける流速曲線では，ボーリ ング孔の上半部で溥水し，下半部で逃水していることが 判明する。

v）揚水して水位が定常状態になった場合の流速曲線 では，水流の動きはすべて上昇しており，孔壁の全区間 から溥水していると判定される。この場合, 曲線の勾配 がほぼ一定の区間は，孔壁からの溥水がほぼ一様である ととを意味する。また，流速の増加する割り合いの大き い（勾配がゆるい）ところは，湧水の多い区間である。

さて, 図-5 の左・右の曲線を比較した場合, 自然水位 状態で逃水区間であった下半部が，揚水によって湧水区 間に変化している。このととは，孔内水位が自然状態の 場合, 地層の中の水压より孔内の静水圧が高く逃水して いたものが，揚水によって水位を下げると静水压が地層 中の水圧より低くなってボーリング孔内に湧水するよう になったことをしめしている。したがって，2つの曲線 の変化は, 孔内の水頭変化にしたがっで抢り, 水頭と地 層内の水圧差によって孔壁から湧水したり逃水すること が明らかである。

左右 2 曲線に見られる流速の差は, 水頭変化による孔 壁からの水の出入りの差をしめしているので，両曲線の 距離（速度の変化量）をとって改めて, 図-6 の自然水 位と揚水水位による水量变化図（曲線 C) を作成する。 孔の断面積が常に一定ならば, 水量変化は, 断面積 $\times$ 速

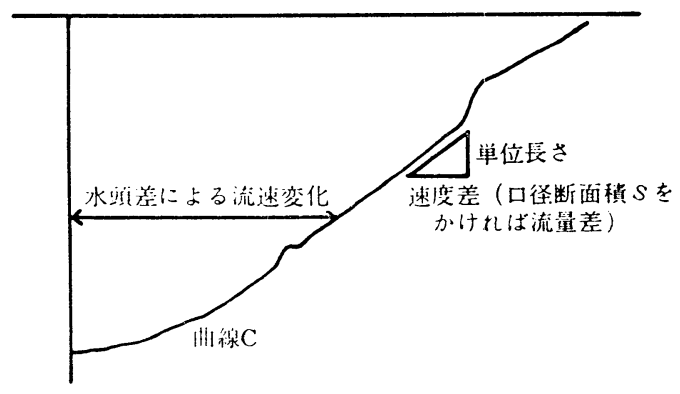

図-6 自然水位と揚水水位による水量 $(v \times S)$ 变化
度変化で表わされる。

図-6 の曲線 C に抢いて，等しい勾配の部分は，水頭 変化に対して，一様な湧水量变化区間である。勾配が急 なところは，ある水頭の変化に対し湧水の变化量の少な いところ，公配がゆるいところは，水頭の変化に対し湧 水量の变化の少ない激しいところ（すなわち透水係数の 大きいところ）意味する。

曲線 C の勾配は, 単位深度長あたりの湧水量変化で しめされる。これを記号 $Q_{i}$ で表わす。 $Q_{i}$ は，ボーリ ング深度区間長 $1 \mathrm{~cm}$ あたりの湧水変化量 $\mathrm{cc}$ でしめす ことにする。

曲線 C に打いて，公配の一定な区間に打ける透水係 数 $(k=\mathrm{cm} / \mathrm{sec})$ は，その区間が水平な均一な連続層か らなると仮定すれば，透水係数它与光る de Dupuit の 式定適用することができる。

$$
k=\frac{Q_{i}}{2 \pi \cdot \Delta P} \cdot \ln \frac{R}{r}
$$

ただし,$\Delta P=$ 水頭変化量, $\mathrm{cm} . R=$ 影響圈半径, $\mathrm{cm}$. $r=$ 孔の有効半径, $\mathrm{cm}$.

ここで，Rについては別途の多孔揚水試験などで求め ることになるが，対数項に入っている関係上，常識的な 值を用いても $k$ に対しては影響が少ない。また，この 項を消去する方法として, 水頭变化 $(\Delta P)$ を 3 回以上 あたえて流速を測定し計算する方法もある。

\section{4. 微流速計の利用}

微流速計は，水流をプロペラの回転によって把える簡 単な機器であるが，適用範囲は工夫次第でさまざまであ る。いくつかの適用例と問題点定以下に述べる。

\section{(1) 定性的利用}

i) 割れ目からの漏水

岩盤の透水試験として，ルジオン試験が一般的であ る。透水区間長を $5 \mathrm{~m}$ として，圧力水を注入し，圧力 $10 \mathrm{~kg} / \mathrm{cm}^{2}$ における $1 \mathrm{~m}$ 区間長の透水量 $(l / \mathrm{min})$ でし

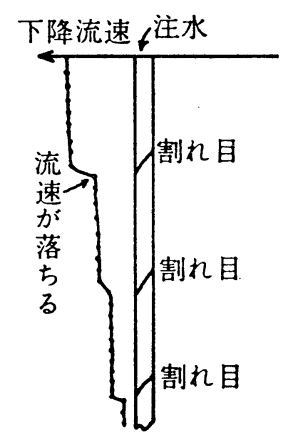

図-7 割れ目から注水が逃げている場合 


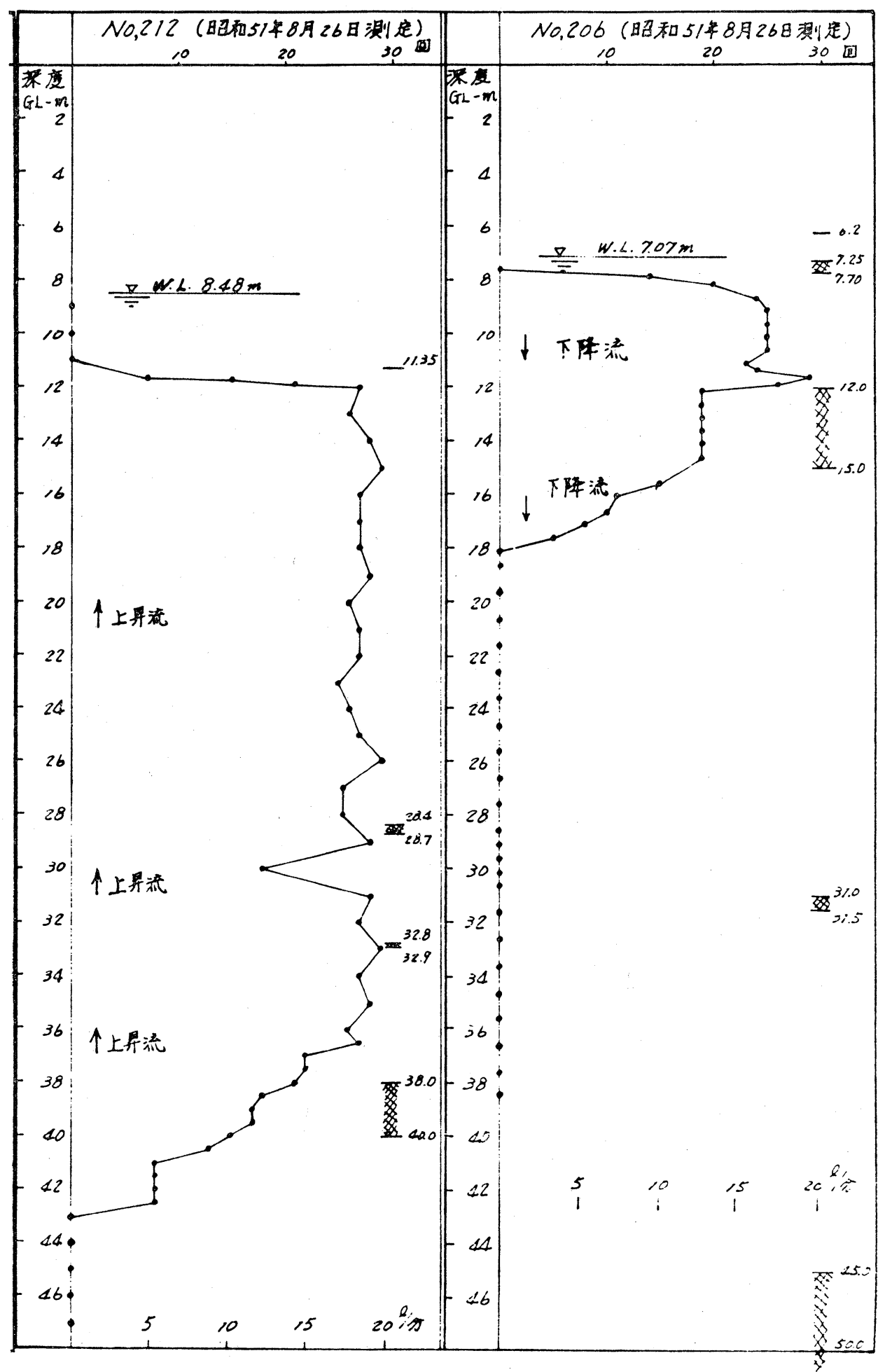

図-8 石兏岩の破砕部からの湧水と逃水 


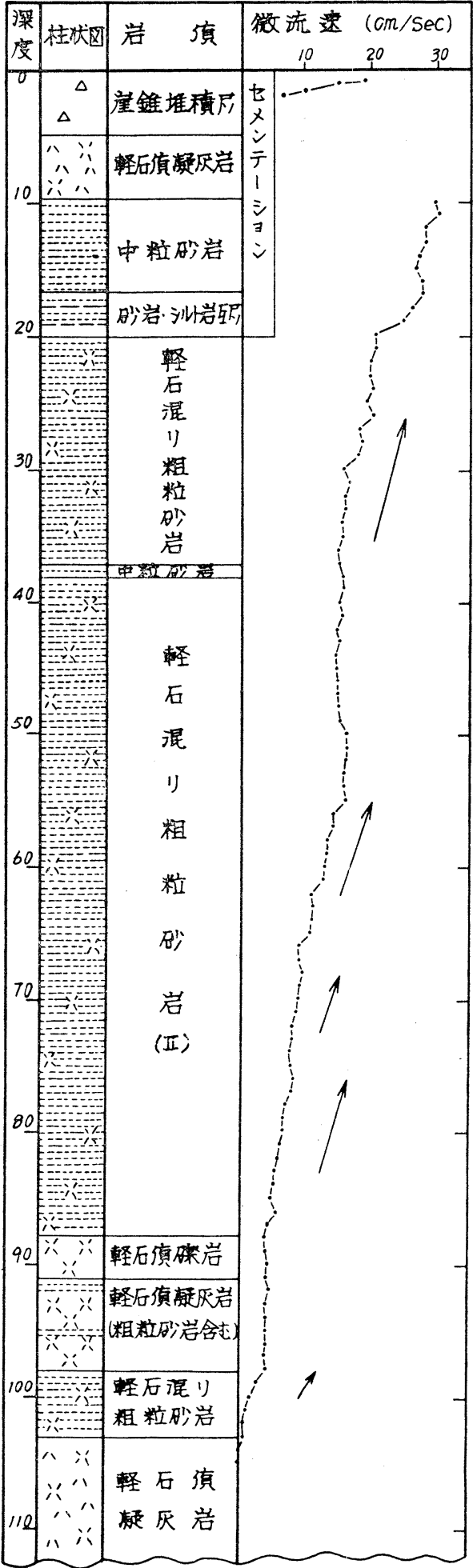

図-9 孔内流速測定結果図
めされるルジオン值が一般的な表示法である。しかし， 岩盤の割れ目は，不規則に発達しており，必ずしも試験 長全区間から逃水が均一におこなわれているわけではな w。

図-7 のように逃水のはげしいボーリング孔にポンプ で注水しながら微流速計で流速を測定してみると，特定 の数個所で流速が低下している。この個所が逃水のはげ しい割れ目の位置であることが明らかである。

図-8 は，石灰岩中に掘削したボーリング孔中での測 定例である。No. 212 孔では，上昇流があり孔底に近い 深度 $43 \mathrm{~m}$ から $37 \mathrm{~m}$ の区間で湧水がある。また，地下 水面に近い深度付近では逃水している。いっぽう，No. 206 孔では，下降流となっている孔内水の流速変化か ら, 地下水面付近の深度 $8 \mathrm{~m}$ 付近で湧水があり, 深度 $12 \mathrm{~m}$ から $18 \mathrm{~m}$ 間で逃水しているのが認められた。ボ ーリングコアーで破砕部と推定される個所它各図の右に 網目でしめしてある肪，大局的には，破砕部の周辺にの み水の動きが存在することがわかる。

ii) 涌水層の検出

第三紀層の被圧地下水地帯の孔井中の測定例 学 図-9 にしめす。流速曲線に勾配のついている個所方湧水層で ある。下方からみれば，深度 $100 \mathrm{~m}$ 付近の軽石混り粗

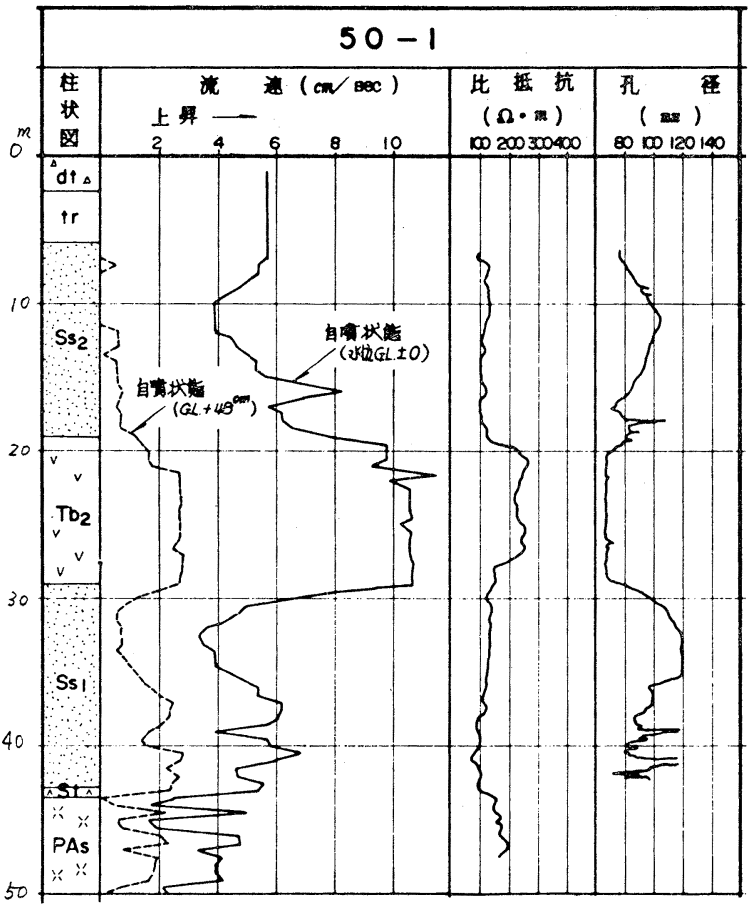

図-10 孔内流速計測定結果図 


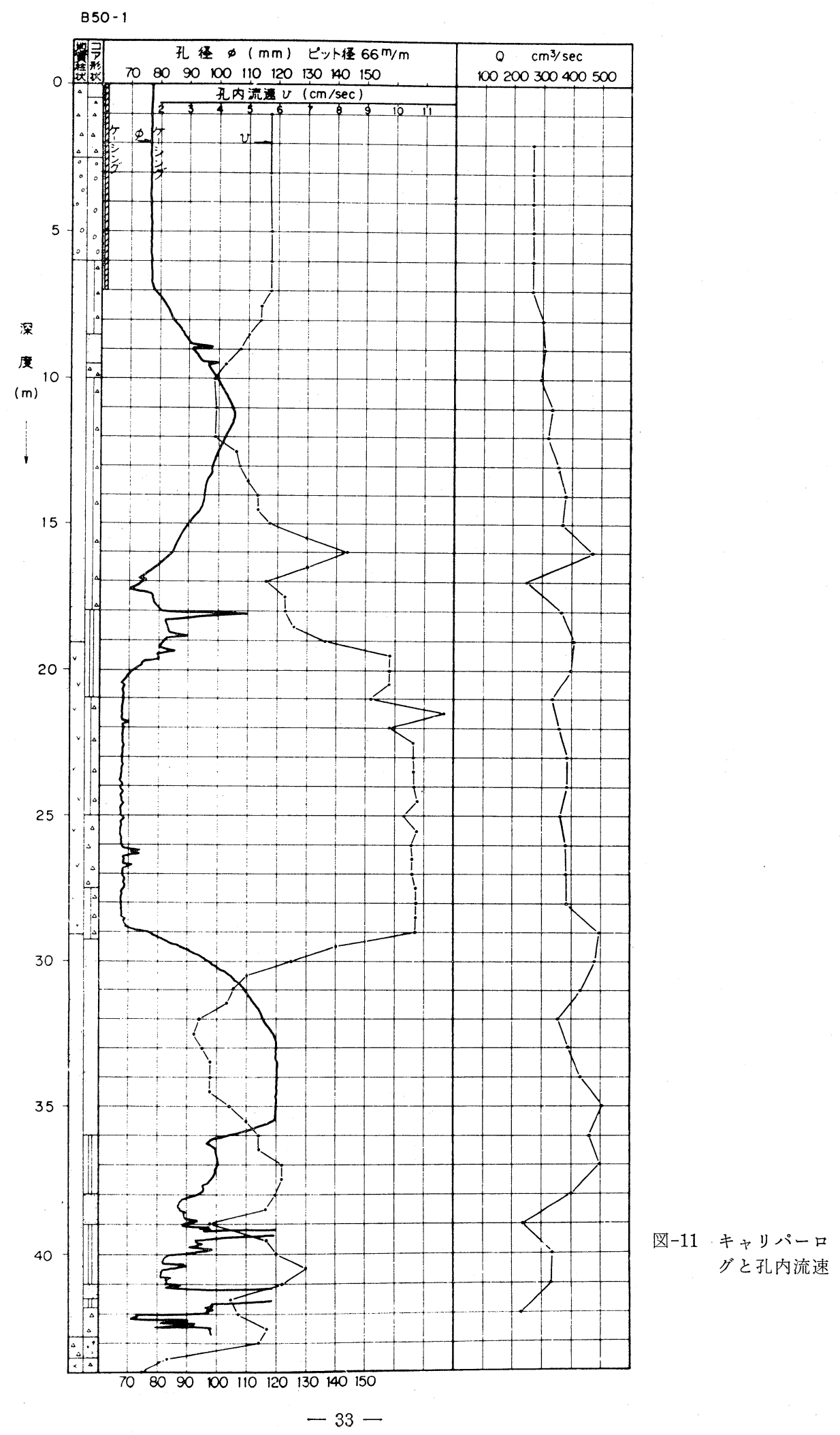


粒砂岩層, 軽石混り粗粒砂岩（II）の下半部, 深度 20 $\mathrm{m} \sim 38 \mathrm{~m}$ 間の軽石混り粗粒砂岩層などから湧水してい るのが判明した (矢印)。地質鑑定の上では, 類似の地 層であっても，透水性が部分によって差のあることがよ くかか。

図-10 も第三紀層の粗粒砂岩層（凝灰質）之凝灰角碎
岩層からなる地域の微流速測定結果である。深度 $18 \mathrm{~m}$ $\sim 28 \mathrm{~m}$ 間の凝灰角砅岩 $\left(T b_{2}\right)$ の下位の砂岩層 $\left(S s_{1}\right)$ から湧水し, 上位の砂岩層 $\left(S s_{2}\right)$ では逃水している。 凝灰角磂岩 $\left(T b_{2}\right)$ では, 湧水も逃水もなく流速はほぼ 一定となっている。この測定は, 自嘪状態の孔井の口元 にケーシングを追加して高さ学かえ口元旉水量を变化さ

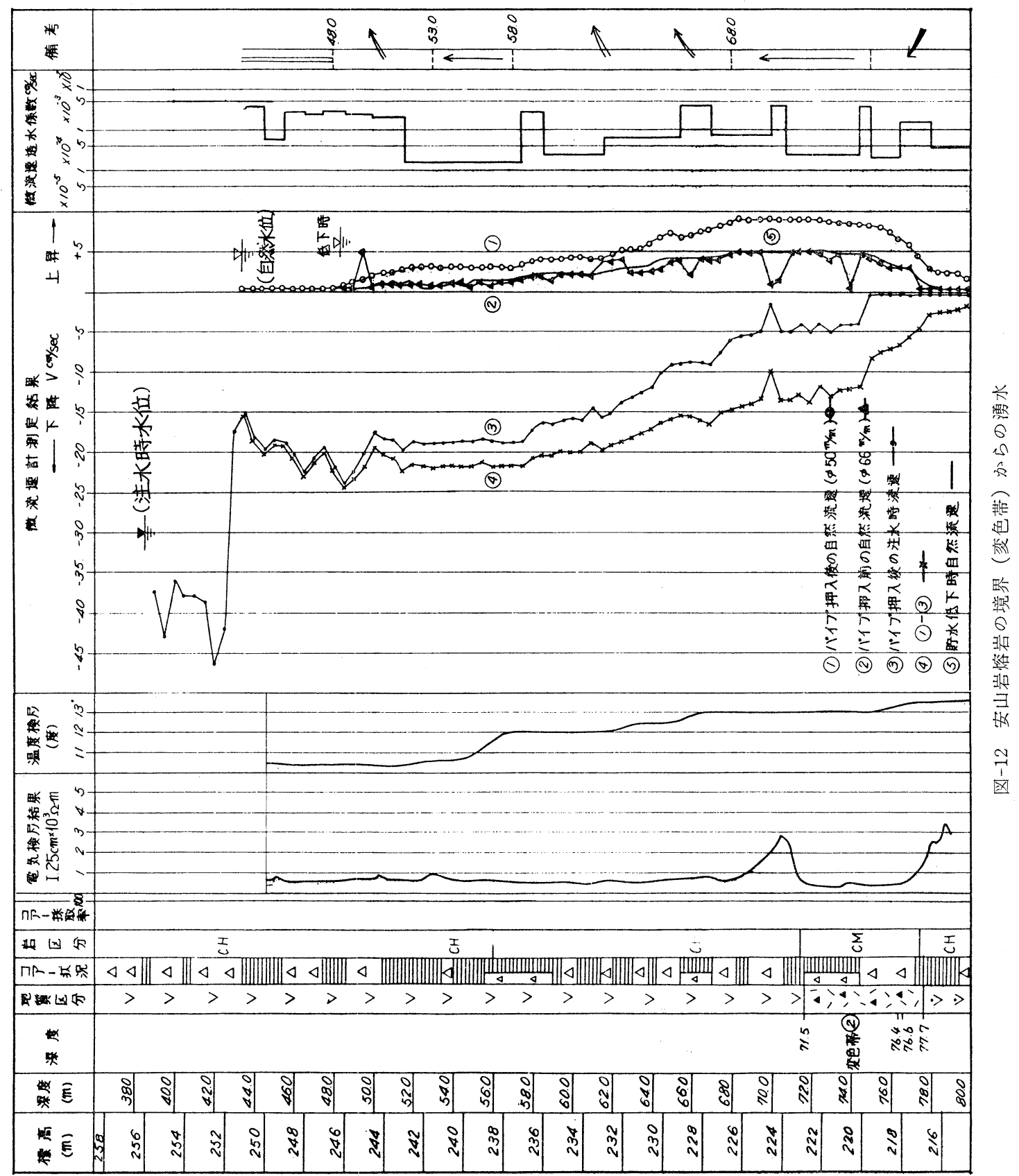


せてから流速を測定したものである。したがって，自噴 状態 $(G L+48 \mathrm{~cm})$ の曲線では, 口元からの湧水量は流 とんどない。この測定曲線の出入りがはげしいととか ら,キャリパーを用いて孔径の変化を測定した結果を, 同図右闌にしめして打く。口径 $66 \mathrm{~m} / \mathrm{m}$ の掘削定打こな ったにもかかわらず，軟質で湧水量の多い下位砂岩層 $\left(S s_{1}\right)$ では孔径分 $120 \mathrm{~m} / \mathrm{m}$ 迄拡大している。孔径拡大 個所では，流速が小さくなり，孔径の小さい個所では流 速が早くなり，キャリパーによる孔径測定曲線と流速曲 線とは，鏡対称のような関係になっている。このような 場合は，各深度において，流速 $(v) \times$ 孔径断面積 $(s)=$ 流 量 $(Q)$ として解析しなければ不適当である。(図-11)

\section{(2) 定量的利用}

あるダムサイトのボーリング孔に抢ける流速測定結果
を図-12 にしめす。ボーリングは，割れ目に富んで安 山岩熔岩学 2 枚貫ら奴いており，2枚の安山岩熔岩の境 界は, 赤褐色の変色常（深度 $71.5 \mathrm{~m} \sim 77.7 \mathrm{~m}$ ) として認 められる。

自然状態に打ける孔内水の移動はすべて上昇流であ る。ボーリング孔内に湧水している個所は, 变色带 (熔 岩境界）汃らで，上部熔岩で徐々に逃水している模様 㚙，曲線 (1)，(2) でしめされる。曲線 (2) は，ボーリン グ掘削直後の孔径 $66 \mathrm{~m} / \mathrm{m}$ の状態に打汀る流速測定結果 である。曲線 (1) は，ボーリング孔にストレーナーとし て，多数のスリットをつけた内径 $50 \mathrm{~m} / \mathrm{m}$ の塩ビ管定湧 入した後での測定結果である。

口径 $66 \mathrm{~m} / \mathrm{m}$ のボーリング孔断面積は, $34.19 \mathrm{~cm}^{2}$ で, 内径 $55 \mathrm{~m} / \mathrm{m}$ の塩ビ管断面積は, $19.63 \mathrm{~cm}^{2}$ となるので,

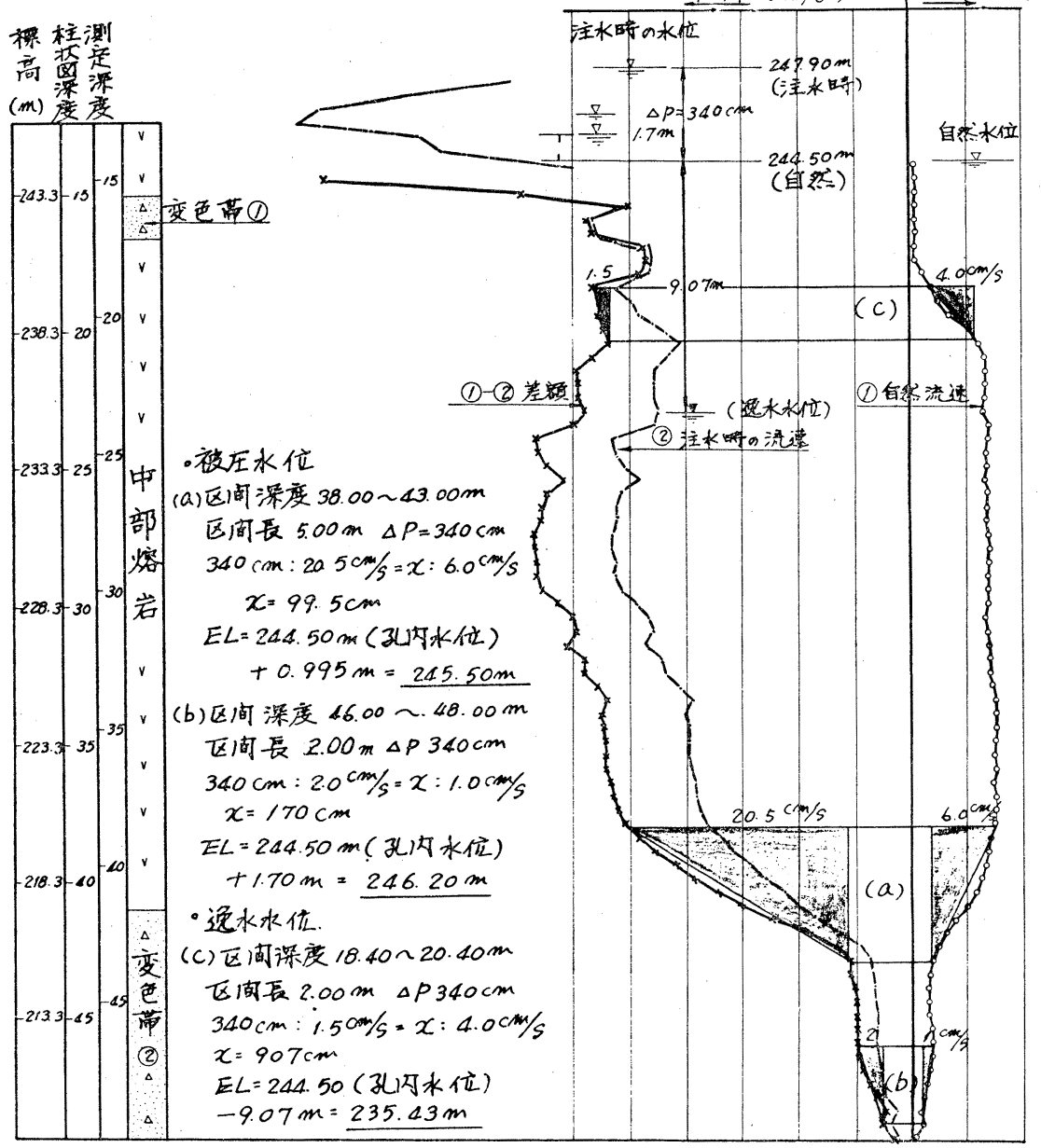

図-13 被圧逸水水位計算例 
同一水量が通過するとすれば，流速比は，34.19/19.63= 1.74 となる筈である。曲線 (1) と曲線 (2) を比較する と，塩ビ管湧入前に $5 \mathrm{~cm} / \mathrm{sec}$ の速速をしめしたところ が $9 \mathrm{~cm} / \mathrm{sec}$ の流速となって抢り，流速比は約 1.8 倍で あることから，ボーリング孔内の流水は，塩ビ管挿入後 は，注とえど管内定通過している結果となって打り，塩 ビ管外壁とボーリング孔壁との隙間を通過して上昇する 水量は僅かであることが明らかとなった。

このボーリング孔内で実施した水温分布を温度検層結 果として図-12 の左から 2 列目にしめして㧍く。変色帯 付近での湧水の温度は $13^{\circ} \mathrm{C}$ であるが，孔内を上昇する に従い水温は $10.5^{\circ} \mathrm{C}$ 宋で低下しており，变色帯をはさ えで上下の安山岩層の地下水温度が異っていることを暗 示する。

ボーリング孔内にポンプによって注水し，孔内水位を 上昇させて，再び流速它測定した結果它 図-12 の曲線 (3) にしめす。孔内水位は, 自然水位に対し約 $3 \mathrm{~m}$ 上昇 したが，乙の水頭変化によって，孔内流速は全区間にわ たり下降流となっている。すなわち，注水によって，孔 内水は，孔壁加ら地山中に逃水している。曲線 (1) (自然 状態）と曲線 (3)（注水状態）の各深度に打ける流速の 差で, 流速变化量曲線 (4)画き, この曲線より求めた 透水係数 図-12 の右方にしめした。安山岩熔岩は, $5 \times 10^{-3} \mathrm{~cm} / \mathrm{sec}$ の透水性部分と $2 \times 10^{-4} \mathrm{~cm} / \mathrm{sec}$ の比較的 難透水性部分とからなっている。它, 地下水位の位置 する深度 $45 \mathrm{~m}$ から深度 $52 \mathrm{~m}$ にかけては, 速水係数が $10^{-3} \mathrm{~cm} / \mathrm{sec}$ のオーダーをしめしており，透水性の良好 な区間となっている。このことは，この区間が現状より
難透水であれば，孔内の自然水位がさらに上部に位置す るであらうこと, また，岩盤中の水位は，逃水の多い個 所（深度）まで降下するであろうことをしめしている。

図-13 は，前例と同じダムサイトに拈けるボーリング の孔内流速湘定結果である。变色帯の付近に 2 個所の湧

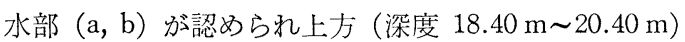
に逸(逃) 水区間（c）功西る。ボーリング孔に注水し， 自然水位から $340 \mathrm{~cm}$ 高く孔内水位を保つと, 孔内水は 下方に流動するようになる。

湧水区間に対し，孔内に注水し水頭を上昇させると， 溥水量は次第に減少し，水頭が大となれば，湧水区間か ら逆に逃水するようになる。この途中に扔いて，湧水も 逃水も起きないような水頭（孔内水位）をもって，その 帯水層の被圧水位と定義する。de Dupuit の公式は,

$$
\begin{aligned}
& k=\frac{Q_{i}}{2 \pi \cdot \Delta P} \cdot \ln \frac{R}{r}, \text { すなはち, } \\
& \Delta P=\frac{Q_{i}}{2 \pi \cdot k} \cdot \ln \frac{R}{r}
\end{aligned}
$$

でしめされるが， $Q_{i}$ は，自然状態の溥水勾配から注水 状態の逃水公配を差引いたものとなっている。したがっ て, 逃水勾配=0の $\Delta P^{\prime}$ を求め机よい。この場合, 図-13 の a 区間 $(5 \mathrm{~m})$ を例にとれば，水頭差 $\left(\Delta P^{\prime}\right)$ $340 \mathrm{~cm}$ で $20.5 \mathrm{~cm}$ の流速差が現われたのであるから， $6.0 \mathrm{~cm}$ の流速差が出る水頭差 $\left(\Delta P^{\prime}\right)$ を求めれ柿よく, 計算式として

$$
340 \mathrm{~cm}(\Delta P): 20.5 \mathrm{~cm}=x \mathrm{~cm}\left(\Delta P^{\prime}\right): 6.0 \mathrm{~cm}
$$
を計算すればよい。すなわち $x=99.5 \mathrm{~cm}$ であって，自 然状態の水位（標高 $244.50 \mathrm{~m}$ ）に $99.5 \mathrm{~cm}$ を加光た標

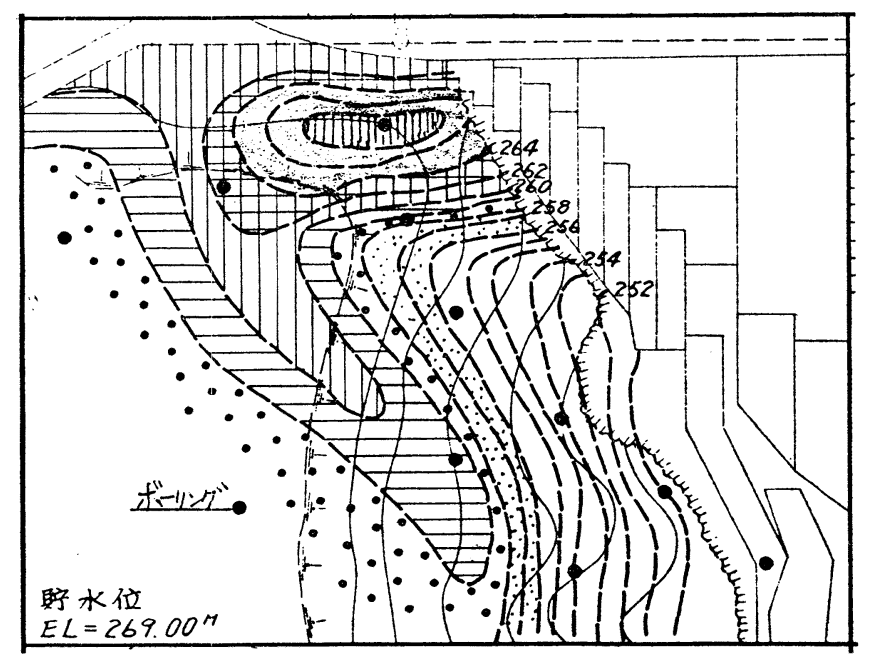

図-14 あるダムサイト右岸の熔岩境界の被圧水頭分布 
高 $244.50 \mathrm{~m}$ の孔内水位において, 湧水も逃水も生じな いことにならう。

この逆に, 逃水区間 $(\mathrm{c})$ に打いて, 孔内水頭定低下 させるとその区間の逃水は停止することになる。この水 頭を冕水（逃水）水位と定義すれば, 計算は, 被圧水位 と同様におこなうことができる。計算の実例を，図-13 に被圧部 ( $\mathrm{a} \cdot \mathrm{b}$ 区間), 逸水部 ( $\mathrm{c}$ 区間) のとれぞれに ついてしめしておいた。

敷地内に打いて, 同一の被圧層について被圧水位を各 ボーリング毎に計算し平面図にしめすことができる。 図-14 はこのよめにして求めた安山岩境界部の被圧水位 図の例である。

\section{5.あとがき}

微流速計の利周は，湧水層の判別，地層の透水係数の 算出以外にも工夫次第によって種々の目的に使用可能々 思われる。たとえば，パイピングの限界圧判定，グラウ 卜効果の判定などがそれである。また，ダムサイトにお
ける透水性断面の作成や，トンネルに沶ける地下水断面 の作成など，従来の単なる孔内水位から判断する資料に 加光て, 水の流動定解析し, 一層具体的飞地下水状況它 判定する上で有効な調査手段となるものと思われる。残 念なことに，未だ充分に普及した調査手法というわけで なく，測定資料も少ないので，今後一層の現場測定例を 加えていきたいと思っている。諸见の御協力と御教示を お願いする次第である。

\section{参 考 文 献}

1) H. Canbefort, G. Mazier (1961): Measurement of Water Flow and Undisturbed Sampling of Cohesive Soil, Proc. 5th ICSMFE (Paris), Vol. 1, pp. 441445.

2）大友 豊 (1970)：深井戸に於ける水の流動度測定 検查方法, 特許出願公告, 昭 45-25029.

3） H. カンブフォール(斎藤, 福住共訳)（1969）：地盤 注入，鹿島出版会。 